\title{
An Economic Analysis of Two Systems and Three Levels of Grazing on Ponderosa Pine -Bunchgrass Range
}

\author{
THOMAS M. QUIGLEY, JON M. SKOVLIN, AND JOHN P. WORKMAN
}

\begin{abstract}
A long-term study of the effects of season-long and deferred rotation grazing at different stocking rates examined cow and calf weight gains. Production functions were derived using stocking rate (AUM's/ha) as a variable input and average summer weight gain (kg/ha) as the output. These functions were optimized economically to determine profit maximizing stocking rates. Optimum stocking rates for season-long grazing on ponderosa pinebunchgrass range were found to be moderate or light over a wide range of feasible price ratios. Optimum stocking rates for deferred rotation grazing did not exceed a moderate level at any feasible price ratio. The ratio of forage price (S/AUM) to the price of livestock $(S / \mathbf{k g})$ must exceed 11 under deferred rotation grazing and 18 under season-long grazing before light stocking becomes the optimum. Based on fall 1979 livestock and forage prices, the stocking rate for profit maximization was moderate (.235 AUM/ha or 10.6 acres/AUM) for deferred rotation and moderate (.312 AUM/ha or 7.9 acres/AUM) for season-long. Season-long grazing also produced a higher net return than did deferred rotation. To remain at the profit maximizing stocking rate while shifting from season-long to deferred rotation, a manager would have to reduce the stocking level at all price ratios.
\end{abstract}

The importance of forage for livestock production on ponderosa pine forests has been described by Reid (1965). This range is also important summer habitat for mule deer (Odocoileus hemionus hemionus), elk (Cervus elaphus nelsoni), and other wildlife. Increasing demands for timber, forage, recreation, and other uses are forcing managers to examine more closely the interrelations and economics associated with market and nonmarket resources. The major thrusts of this paper are economics of different grazing systems and stocking rates.

With a few exceptions (Bement 1969, Shoop and Mcllvain 1971, Pearson 1973, Whitson and Ragsdale 1976), stocking rates and grazing systems have not been examined in economic terms. Animal response to rates and systems, however, has received much attention (Johnson 1953, Klipple and Costello 1960, Reed and Peterson 1961, Skovlin 1962, Houston and Woodward 1966). Herbage response to rates and systems has also been thoroughly treated and recently was reviewed by Van Poollen and Lacey (1979). Hart (1978) demonstrated how stocking rate models can be applied to various rangeland situations.

The merits for recommending one system or stocking rate over another has largely been based on environmental considerations or a maximization of either forage production or animal weight gain. Economic rationale is typically lacking or only broadly generalized.

Two grazing systems, deferred rotation and season-long, were studied at 3 stocking intensities for a 10-year period in the Blue Mountains of eastern Oregon and Washington. Results relating to forage, animal, and timber response, watershed impacts, and cattle and wildlife interactions have been published (Skovlin et al. 1976).

\footnotetext{
The authors are, respectively, economist and range scientist (retired), USDA Forest Service, Pacific Northwest Forest and Range Experiment Station, La Grande, Ore. 97850; and professor, Department of Range Science, Utah State University 84322.

Manuscript received June $17,1982$.
}

Without regard for economic resources, they reported greatest rangeland recovery under lightly stocked deferred rotation grazing. To further exploit this information, we have subjected the animal response data to economic analysis to determine profit maximizing stocking rates.

\section{Methods}

Beginning in 1955 and ending in 1964, 2 replications each of 6 different native rangeland units were grazed for a 4-month summer season; 2 control units were observed but not grazed. Pastures ranged in size from 250 to 400 ha. Deferred rotation (DR) was practiced on 6 pastures where cattle annually alternated between halves ( $A$ and $B$ ) of the pasture (i.e., 2 months in A, then graze B; next year $B$ then $A)$. The study was designed to have stocking rates of 4,3 , and 2 "useable" hectares/ animal unit month $(10,7.5$, and 5 acres/AUM) or $.25, .33$, and .50 AUM's per usable hectare with 2 pastures receiving each of the 3 stocking rates (light, moderate, and heavy). The same stocking rates and design were used on 6 pastures grazed season-long (SL).

Stocking rates and weight gains are reported in total hectares, rather than usable hectares, for these reasons: (1) lease rates of privately owned ponderosa pine-bunchgrass range are generally determined on a total area basis, as opposed to a usable area basis, (2) usable hectares vary from year to year and within years because of use and production fluctuations (Harris 1954) and because of canopy closure and regeneration (Pace 1958), and (3) definition of usable range may be indistinct because of variable slope, distance to water, timber density, etc. Use of total hectares better explained the variability of the response data and also why actual stocking rate (AUM/hectare) differed from the original target rates (.25, .33 , and .50 AUM's per usable hectare).

Cow and calf gain or loss was monitored for each pasture for each of the 10 years studied. Regression techniques were applied to the weight gain/loss data to determine production functions (relationship between inputs and outputs) with stocking rate as the variable input and animal gain as the output. Separate animal gain production functions were derived for season-long and deferred rotation grazing. Breeding performance and long-term response by individual animals were not determined during this study. Thus, if the study treatments appreciably affected reproduction and longterm responses of the cattle, the effect of the treatments on economic returns could have been different than those projected in this paper. Whenever possible animal gain production functions should include effects of treatments on reproduction and longterm changes in animal performance.

The production functions were analyzed economically to determine the optimum stocking rates for season-long and for deferred rotation. These optima were then compared to determine which of the 2 grazing methods was the most profitable. Finally, the production functions were analyzed to determine how each optimum was affected by changes in livestock and AUM prices. 


\section{Results}

Animal response, in terms of weight gain or loss, was measured for each year of treatment by pasture and averaged over the 10 years of the study. The 10-year average seasonal cow and calf weight gain/loss in kilograms per hectare for each pasture is shown in Table 1 . The actual stocking rates (available AUM/hectare) which were achieved for each pasture are also shown.

Table 1. Ten-year average seasonal weight gain/loss by pasture for cows and calves.

\begin{tabular}{|c|c|c|c|c|}
\hline \multirow{2}{*}{$\begin{array}{l}\text { Grazing system, } \\
\text { replication, } \\
\text { and pasture }\end{array}$} & \multirow{2}{*}{$\begin{array}{l}\text { Stocking, } \\
\text { AUM's/ha }\end{array}$} & \multicolumn{3}{|c|}{ kg gain/loss per ha } \\
\hline & & Cow & Calf & Calf + cow \\
\hline \multicolumn{5}{|l|}{$\begin{array}{l}\text { Deferred rotation } \\
\text { Replicate 1: }\end{array}$} \\
\hline $\begin{array}{l}1 \\
2 \\
3\end{array}$ & $\begin{array}{l}.158 \\
.198 \\
.331\end{array}$ & $\begin{array}{r}.66 \\
.27 \\
-1.15\end{array}$ & $\begin{array}{l}3.86 \\
4.27 \\
6.31\end{array}$ & $\begin{array}{l}4.52 \\
4.54 \\
5.16\end{array}$ \\
\hline $\begin{array}{l}\text { Replicate 2: } \\
\quad 1 \\
2 \\
3\end{array}$ & $\begin{array}{l}.153 \\
.259 \\
.274\end{array}$ & $\begin{array}{c}.50 \\
1.40 \\
.12\end{array}$ & $\begin{array}{l}3.53 \\
5.73 \\
6.00\end{array}$ & $\begin{array}{l}4.03 \\
7.13 \\
6.12\end{array}$ \\
\hline \multicolumn{5}{|l|}{ Season-long } \\
\hline $\begin{array}{l}1 \\
2 \\
3\end{array}$ & $\begin{array}{l}.198 \\
.294 \\
.306\end{array}$ & $\begin{array}{r}.64 \\
.53 \\
-.45\end{array}$ & $\begin{array}{l}4.61 \\
6.62 \\
6.10\end{array}$ & $\begin{array}{l}5.25 \\
7.15 \\
5.65\end{array}$ \\
\hline $\begin{array}{l}\text { Replicate 2: } \\
1 \\
2 \\
3\end{array}$ & $\begin{array}{l}.215 \\
.284 \\
.329\end{array}$ & $\begin{array}{r}1.58 \\
1.60 \\
.90\end{array}$ & $\begin{array}{l}5.06 \\
6.33 \\
7.47\end{array}$ & $\begin{array}{l}6.64 \\
7.93 \\
8.37\end{array}$ \\
\hline
\end{tabular}

The production function selected to fit the data follows the quadratic form:

$$
Y=a(A U M)+b(A U M)^{2}
$$

where, $Y=$ kilograms of gain/loss per hectare (output)

AUM = stocking rate in AUM's/ hectare (variable input) and $a$ and $b=$ regression coefficients.

Production functions were derived using cow + calf gain as the output. The basic objective of the analysis was to maximize the net return from livestock over the 4-month summer grazing season. Cow and calf gains were aggregated for these reasons: (1) if calf gain alone were considered, the health of the cows and their response to stocking would be ignored, (2) the decision by an operator at the end of a grazing season to retain some calves and almost all cows demonstrates that the value of replacement heifer calves and those cows not culled from the herd must be at least equal to their market value (including the summer grazing season gain), and (3) the value of the cow gain, although not totally captured through cull cow sales, is recognized through reduced winter feed requirements, veterinary costs, death loss, etc. Alternative approaches could be utilized as a measure of output. This approach recognizes that value does exist in cow gain. Examining calf gain only would result in a heavier stocking rate recommendation.

The production functions are shown graphically and algebraically (Fig. 1). In each instance the correlation coefficient exceeded $.90\left(\mathrm{DR}: \mathrm{R}^{2}=.899\right.$ and $\left.\mathrm{SL}: \mathrm{R}^{2}=.985\right)$ and model $F$-tests were significant at the $95 \%$ level. The production functions differed significantly at the $90 \%$ level ( $F$-test).

The profit maximizing stocking rate is the one where the last increment of output (output gain) costs as much as it contributes to revenue. At this point marginal cost is equal to marginal revenue

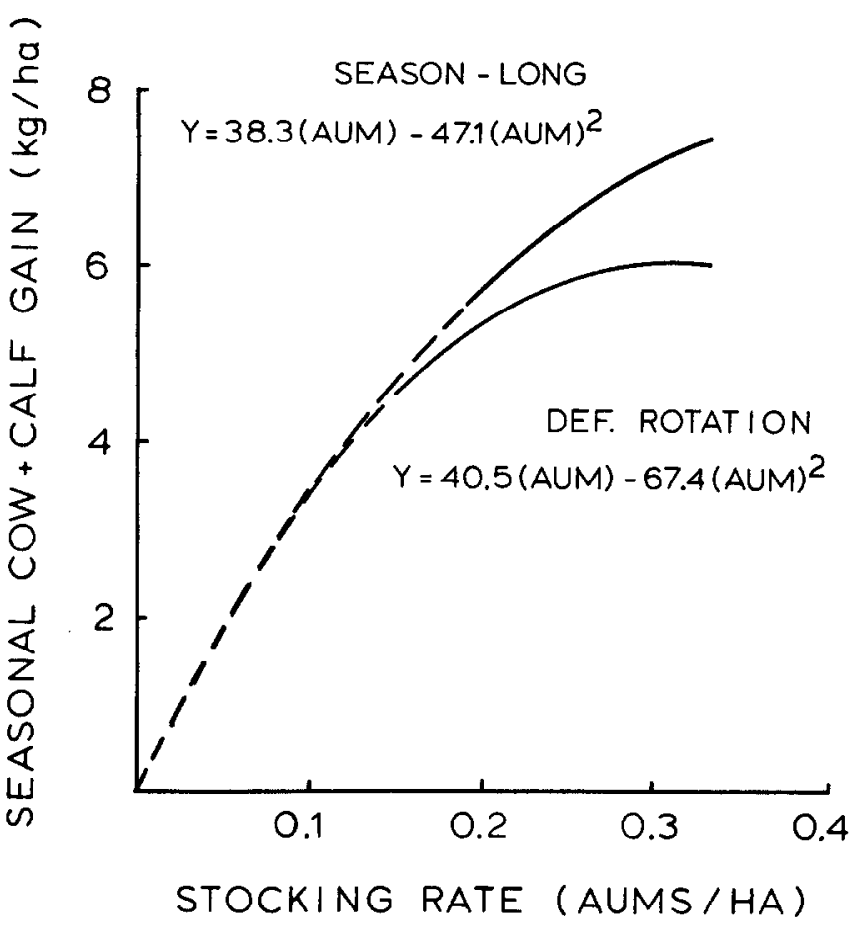

Fig. 1. Livestock weight gain production functions.

and profit is maximized. The profit maximizing stocking rate is determined by setting the marginal physical production (MPP $A$ AM) or the slope of the production function (dY/d(AUM) equal to the ratio of the input price $\left(\mathbf{P}_{\mathrm{AUM}}\right)$ to output price $\left(\mathrm{P}_{\mathbf{Y}}\right)$ or $\mathbf{P}_{\mathrm{AUM}} / \mathbf{P}_{\mathbf{Y}}$.

This can be illustrated for the deferred rotation production function by equating the rate of change (first derivative) of livestock gain (Y) with respect to stocking rate $(A U M), d Y / d(A U M)=$ 40.5 - 134.8(AUM), with the ratio of the price of grazing to the price of livestock, $P_{A U M} / P_{Y}$. The prices employed in this analysis are the October 1979 weighted (in terms of contributions to production by animal class) averaged price for cows and heifers and steers, $P_{Y}=\$ 1.45 / \mathrm{kg}(\$ .658 / \mathrm{lb})$ and the 1979 average rate for pasturing cattle on privately owned non-irrigated land, \$7.53/AUM (United States Department of Agriculture 1980). These prices are combined with the non-lease variable costs per AUM of $\$ 5.34$. The non-lease variable costs were determined by adjusting the nonlease costs reported in Nielsen and Workman (1971) to a 1979 equivalent by using the index of prices paid by farmers (United States Department of Agriculture 1980). Thus the variable cost associated with grazing is $\$ 12.87 / \mathbf{A U M}$. Both prices represent the average for the 11 Western States. Actual prices for an individual ranch or allotment will vary from the averages used here. Substituting these values into the marginal analysis equation:

$$
40.5-134.8(\text { AUM })=12.87 / 1.45
$$

and solving for AUM we obtain .235 AUM/ha or $4.3 \mathrm{ha} / \mathrm{AUM}$ (10.6 acre/AUM) which is the optimum stocking rate for maximum profit.

Thus, the deferred rotation stocking rate to maximize net return from cow + calf gain is $.235 \mathrm{AUM} /$ ha based on average 1979 prices. It should be noted that the 1979 prices form a price ratio of 8.88 $\left(P_{\text {AUM }}=\$ 12.87 P_{Y}=\$ 1.45\right)$.

Optimum stocking rate based on these average 1979 prices for season-long cow + calf gain is $.312 \mathrm{AUM} /$ ha ( 7.9 acre/AUM). Optimum stocking rates calculated for various $\mathbf{P}_{\mathrm{AUM}} / \mathbf{P Y}_{\mathbf{Y}}$ price ratios are shown in Figure 2. Once the appropriate price ratio has been calculated, one can examine Figure 2 and determine the corresponding profit maximizing or loss minimizing stocking rate. 


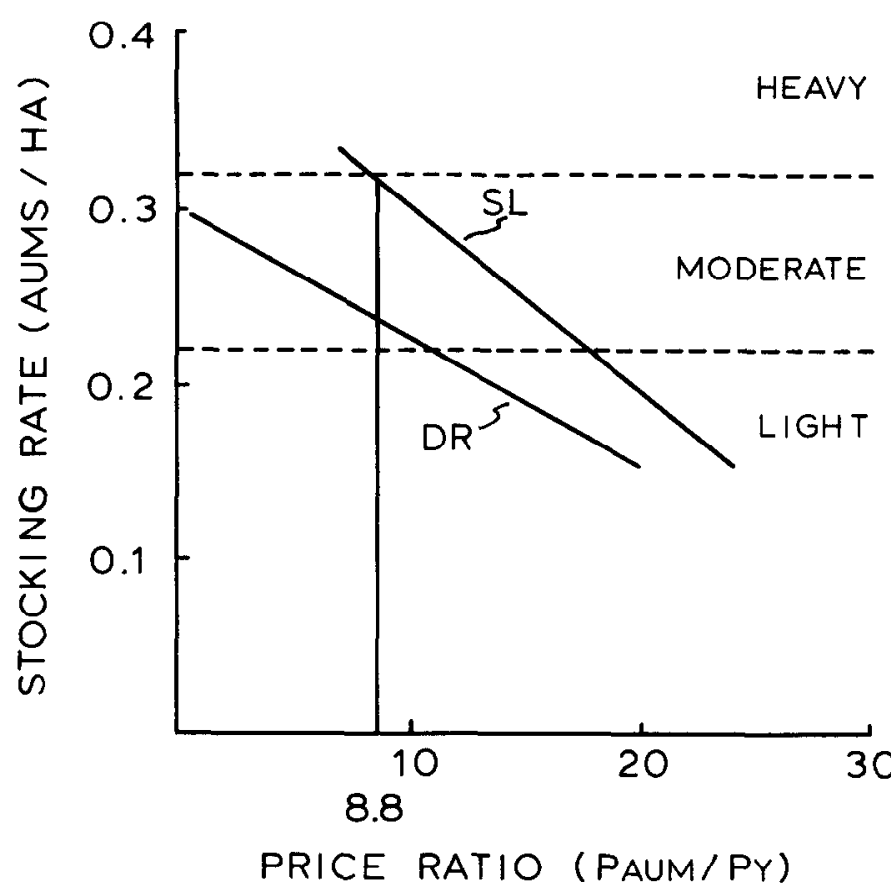

Fig. 2. Optimum stocking rates versus price ratio.

Calculation of profit or loss takes both fixed and variable costs into account. Fixed costs do not vary with stocking rate. Examples are property taxes and interest on investment. Variable costs are those that do change with changes in stocking rate, such as the costs of transporting livestock, grazing fees, livestock herding, and veterinary services. Based on the optimum stocking rates dictated by the above 1979 prices, season-long grazing provided a per hectare net return to forage (value of livestock gain per hectare minus per hectare value of forage grazed) of $\$ 6.65$ while deferred rotation grazing produced a per hectare return of only $\$ 5.38$. If the implementation of deferred rotation necessitated construction of fences, the per hectare return would be slightly less.

\section{Sensitivity to Price Changes}

Sensititivity of the profit maximizing stocking rates to changes in price can also be determined from Fig. 2. The steeper the slope, the more sensitive the optimum stocking rate is to price changes. Thus, season-long (SL) optima are more sensitive than deferred rotation (DR) optima and an operator managing under a seasonlong system of grazing would find the profit maximizing stocking rate changing more rapidly as livestock and grazing prices change than would an operator managing under a deferred rotation system.

Managing strictly for profit maximization would result in a heavy stocking rate (.32 AUM's/ha or greater) under a season-long system of grazing whenever the price ratio is less than 8 . Observations of ecological trends in those pastures heavily stocked indicate that the long-term season-long production function tapers off more rapidly at heavy stocking rates (Skovlin et al. 1976). These trends would likely result in an eventual shift of the production function downward. Thus, on ponderosa pine-bunchgrass ranges a grazing system that shows larger short-term profits by heavy stocking may, if managed under that system for the long term, result in decreased opportunities for future production. In contrast with season-long, the profit maximizing stocking rate for deferred rotation does not result in a heavy rate for any of the feasible price ratios shown. Thus, for a wide range of feasible price ratios under season-long and for all ratios under deferred rotation, a moderate (between .22 and .32 AUM's/ ha) or light (less than .22 AUM's/ha) stocking rate is optimum.

From the ponderosa pine-bunchgrass data analyzed here, it is apparent that at all price ratios shown in Figure 2, the profit maximizing stocking rate is greater for season-long than for deferred rotation. This conclusion contradicts the widespread belief that a heavier stocking rate can be based under deferred rotation than under season-long grazing. Thus, to remain in the profit maximizing range of stocking rates a manager should reduce, rather than increase, stocking as the transition is made from season-long to deferred rotation.

Light stocking does not become the profit maximizing rate until the price of grazing $\left(P_{\mathrm{AUM}}\right)$ becomes expensive relative to the livestock price (Py). If the livestock price were $\$ 1.45 / \mathrm{kg}$, under a deferred rotation system, light stocking would become optimum when the price of an AUM exceeds \$16. Under season-long grazing, AUM price would have to reach $\$ 26$ before light stocking became optimum.

Given existing price ratios, these production functions suggest that, for periods of 10 years or less, profits from grazing ponderosa pine-bunchgrass range are greater when stocked at a moderately heavy rate under a season-long system. If the landowner's management horizons were greater than 10 years, stocking would likely be less. Most private landowners, however, are managing their resources to maximize short-term profits to pay mortgages, taxes, support a household, etc.

Many of these private landowners are permittees on federal lands and are pressured to implement advanced grazing systems with reduced stocking. From their economic viewpoint, they desire season-long grazing with moderately heavy stocking. The public land managers, however, are attempting to manage for sustained long-term yields of multiple resources, not profit. Much has been written relative to the impact of grazing on riparian zones, aquatic ecosystems, and other resources. Meehan and Platts (1978) reported that the aquatic ecosystem and fisheries resource were adversely affected by heavy stocking and season-long grazing. In the Blue Mountains of eastern Oregon and Washington, 285 terrestrial wild life species are either directly dependent on riparian zones or utilize them more than other habitats (Thomas 1979). Skovlin et al. (1968) found a trade-off between livestock and big game useparticularly in rested or deferred grazing areas. Thus, where profit is not the primary management concern on ponderosa pinebunchgrass range, grazing systems and stocking rates will likely vary from the profit maximizing rates. Models of the type reported here can be useful in determining the cattle gain opportunities possible from alternative grazing systems and stocking levels.

Although the impact of wildlife populations on stocking rate did not adversely affect the livestock production reported, significant increases in wildlife populations could cause shifts in livestock production relationships. Further research is needed to define the interactions which exist between livestock and wildlife.

\section{Literature Cited}

Bement, R.E. 1969. A stocking-rate guide for beef production on bluegrama rate. J. Range Manage. 22:83-86.

Hart, R.H. 1978. Stocking rate theory and its application to grazing on rangelands. Proc. 1st Int. Range. Cong., Denver, Colo., 1978.

Harris, R.W. 1954. Fluctuations in forage utilization on ponderosa pine ranges in eastern Oregon. J. Range Manage. 7:250-255.

Houston, W.R., and R.R. Woodward. 1966. Effects of stocking rates on range vegetation and beef cattle production in the northern Great Plains. USDA Tech. Bull. 1357.

Johnson, W.M. 1953. Effect of grazing intensity upon vegetation and cattle gains on ponderosa pine-bunchgrass ranges of the Front Range of Colorado. USDA Circ. 929.

Klipple, G.E., and D.F. Costello. 1960. Vegetation and cattle responses to different intensities of grazing on shortgrass ranges on the central Great Plains. USDA Tech. Bull. 1216. 
Mechan, W.R., and W.S. Platts. 1978. Livestock grazing and the aquatic environment. J. Soil and Water Conserv. 33:274-278.

Nielsen, D.B., and J.P. Workman. 1971. The importance of renewable grazing resources on federal lands in the 11 western states. Utah Agr. Exp. Sta. Cir. 155. Utah State Univ., Logan.

Pace, C.P. 1958. Herbage production and composition under immature ponderosa pine stands in the Black Hills. J. Range Manage. 11:238-243.

Pearson, H.A. 1973. Calculating grazing intensity for maximum profit on ponderosa pine range in northern Arizona. J. Range Manage. 26:277-279.

Reed, M.J., and R.A. Peterson. 1961. Vegetation, soil, and cattle responses to grazing on northern Great Plains range. USDA Tech. Bull. 1252.

Reid, E.H. 1965. Forage production in ponderosa pine forests. Soc. Amer. Forest. Proc. 1964:61-64.

Shoop, M.C., and E.H. Mcllvain. 1971. Why some cattlemen overgrazeand some don't. J. Range Manage. 24:242-257.

Skovlin, J.M. 1962. Cow and calf weight trends on mountain summer range. USDA Forest Serv. Res. Note 220. Pac. Northwest Forest and Range Exp. Sta., Portland, Ore.
Skovlin, J.M., P.J. Edgerton, and R.W. Harris. 1968. The influence of cattle management on deer and elk. Trans. 33rd North Amer. Wildl. and Nat. Resour. Conf. Wildl Manage. Inst., Washington, D.C.

Skovlin, J.M., R.W. Harris, G.S. Strickler, and G.A. Garrison. 1976. Effects of cattle grazing methods on ponderosa pine-bunchgrass range in the Pacific Northwest. USDA Forest Serv. Tech. Bull. 1531.

Thomas, J.W. (Tech. Ed.). 1979. Wild life habitats in managed forests - the Blue Mountains of Oregon and Washington. USDA Forest Serv. Agr. Handb. No. 553. U.S. Gov. Print. Off., Washington, D.C.

United States Department of Agriculture. 1980. Agricultural prices, February 1980. Crop Rep. Board, Economics, Statistics, and Cooperatives Serv., Washington, D.C.

Van Poollen, H.W., and J.R. Lacey. 1979. Herbage response to grazing systems and stocking intensities. J. Range Manage. 32:250-253.

Whitson, R.E., and B.J. Ragadale. 1976. Variable rangeland lease considerations. Rangeman's J. 3:143-145. 